\title{
R-fluoxetine Increases Extracellular DA, NE, As Well As 5-HT in Rat Prefrontal Cortex and Hypothalamus: An in vivo Microdialysis and Receptor Binding Study
}

Susanne Koch, Ph.D., Kenneth W. Perry, M.S., David L. Nelson, Ph.D., Richard G. Conway, M.S., Penny G. Threlkeld, M.S., and Frank P. Bymaster, M.S.

The selective serotonin reuptake inhibitor fluoxetine consists of equal amounts of $R$ and $S$ stereoisomers. In this study, we investigated the pharmacologic properties of the stereoisomers using transporter and receptor binding assays and in vivo microdialysis in freely moving rats. Binding to the transporter confirmed selectivity of $R$ - and S-fluoxetine for the 5-HT transporter versus the dopamine (DA) and norepinephrine (NE) human transporters. Receptor binding studies demonstrated significant affinity of $R$-fluoxetine, but not S-fluoxetine, for human 5- $\mathrm{HT}_{2 \mathrm{~A}}$ and $5-\mathrm{HT}_{2 \mathrm{C}}$ receptor subtypes. Functional GTP $\gamma S$ binding studies indicated that $\mathrm{R}$-fluoxetine is an antagonist at $5-\mathrm{HT}_{2 A}$ and $5-H T_{2 C}$ receptors. In microdialysis studies, acute $R$ - and $S-$ fluoxetine increased extracellular levels of 5-HT, DA, and
NE in prefrontal cortex (PFC), but R-fluoxetine caused significantly greater increases of catecholamines. $R$ fluoxetine increased extracellular levels of 5-HT and NE in PFC, nucleus accumbens, and hypothalamus, whereas it increased dopamine in PFC and hypothalamus, but not in $D A$-rich nucleus accumbens and striatum, thus indicating a regionally selective effect. The unexpected increases of extracellular catecholamines by a selective 5-HT uptake inhibitor like R-fluoxetine may be due to its antagonism of $5-\mathrm{HT}_{2 \mathrm{C}}$ receptors.

[Neuropsychopharmacology 27:949-959, 2002]

(C) 2002 American College of Neuropsychopharmacology.

Published by Elsevier Science Inc.
KEY WORDS: R-Fluoxetine; Antidepressant; Microdialysis; Dopamine; Serotonin; Norepinephrine

Most drug treatments for depression elevate monoaminergic neurotransmission, in particular serotonin (5-HT),

From the Lilly Research Laboratories, Neuroscience Discovery Research, Lilly Corporate Center, Indianapolis, IN 46285

Address correspondence to: Frank P. Bymaster, Research Laboratories, Neuroscience Discovery Research, Lilly Corporate Center, Indianapolis, IN 46285. Tel.: (317) 276-2951; Fax: (317) 276-5546;

E-mail: f.bymaster@lilly.com

Received January 25, 2002; revised April 10, 2002; accepted April 17, 2002.

Online publication: 5/17/02 at www.acnp.org/citations/ Npp051702309. norepinephrine (NE) and/or dopamine (DA). Initial agents to treat depression, like tricyclics (TCAs), have many bothersome side effects including cardiotoxicity that are mediated by their interaction with adrenergic, cholinergic and histaminergic systems (Cusack et al. 1994; Bourin and Baker 1996). The selective serotonin reuptake inhibitors (SSRI) represented a new generation of compounds for the treatment of depression (for review see Wong et al. 1995). Unlike TCAs, SSRIs are devoid of adrenergic, cholinergic, and histaminic activity and show a much better side effect profile and higher compliance in patients (Stahl 1998; Westenberg 1999). The SSRIs selectively block the serotonin transporter, thus inhibiting uptake of released serotonin back into 
the nerve terminal and enhancing serotonergic neurotransmission. The clinical success of the antidepressant SSRI fluoxetine (FLX, Prozac, Wong et al. 1995) has strengthened the initial serotonin hypothesis of depression postulated by Van Praag and Korf (1970). Increasing serotonin levels alone, however, is not the full answer to the diverse clinical symptoms of depression. There is also a role for NE, as seen with TCAs and the more recent dual 5-HT/NE reuptake inhibitors (Duloxetine, Berk et al. 1997; Venlafaxine, Kent 2000) and selective NE reuptake inhibitors (Atomoxetine (Tomoxetine), Wong et al. 1982; Reboxetine, Wong et al. 2000). The involvement of different neurotransmitter systems also underlines the complexity of depression. In patients successfully treated with either a TCA or NE reuptake inhibitor but not with a SSRI, a subsequent depletion of NE levels will precipitate a relapse into the depressive state (Miller et al. 1996a,b).

Besides the involvement of the 5-HT and NE systems, the DA system is affected as well. Anecdotal drug combinations, bupropion therapy and electroconvulsive therapy (ECT) are relevant treatment strategies, all having in common the elevation of DA levels. An abundance of literature is emerging on the role of DA in depression (Brown and Gershon 1993; Fibiger 1995; Ebert and Lammers 1997). Successful treatment with ECT in Parkinson's Disease (Atre-Vaidya and Jampala 1988) and severe cases of depression (DasGupta 1998; Strober et al. 1998) indicates a DA imbalance, and indeed, ECT elevates extracellular DA levels (Zis et al. 1991; Yoshida et al. 1997, 1998). Additionally, anhedonia is one of the hallmarks of depression and is linked to DA deficiency (for review, see Pani and Gessa 1997; Heinz 1999). Thus, modulation of a single monoamine system is not the only approach to treating depression, and enhanced interaction among monoaminergic systems may increase clinical efficacy or decrease the time to onset of activity. Clinically, treatments elevating one or more of the monoamines, DA, 5-HT, and NE have been successful (Seth et al. 1992; Richelson 1996; Stahl 1998; Corrigan et al. 2000).

The $5-\mathrm{HT}_{2 \mathrm{~A}}$ receptor is also implicated in the treatment of depression (Stefanski and Goldberg 1997) and activation thereof has been linked to undesired side-effects such as altered sleep, anxiogenesis, and sexual dysfunction (Pullar et al. 2000). Furthermore, activation of the $5-\mathrm{HT}_{2 \mathrm{~A}}$ receptor or blockade of the $5-\mathrm{HT}_{2 \mathrm{C}}$ receptor increases extracellular DA and NE in the prefrontal cortex of the rat brain (Millan et al. 1998; Gobert and Millan 1999). Blockade of the 5- $\mathrm{HT}_{2}$ receptor with mesulergine elevated extracellular DA levels in the nucleus accumbens and selective blockade of the $5-\mathrm{HT}_{2 \mathrm{C}}$ receptor increases mesolimbic DA levels (Di Matteo et al. 1998; Di Matteo et al. 1999). In addition, Di Matteo (2000) suggested that the antidepressants amitryptyline and mianserin elevate DA in the nucleus accumbens through a $5-\mathrm{HT}_{2 \mathrm{C}}$ receptor-sensitive mechanism.
Considering the importance of interaction of the 5-HT system with the DA and NE systems, we investigated the effects of R-FLX on these systems. We evaluated the interactions of R- and S-FLX with monoaminergic receptors and transporters, as well as their effects on extracellular levels of 5-HT, DA, and NE, using in vivo microdialysis.

\section{MATERIALS AND METHODS}

\section{Drugs}

Fluoxetine, norfluoxetine and their enantiomers, citalopram, fluvoxamine, paroxetine, and sertraline, were prepared by Lilly Laboratories. Desipramine and imipramine were purchased from Sigma Co. (St. Louis, MO).

\section{Transporter Binding}

Membranes from HEK 293, MDCK, and HEK 293 cell lines transfected with human 5-HT, NE, and DA transporters, respectively, were obtained from Receptor Biology, Inc. (Beltsville, MD). All assays were performed in triplicate in a final volume of $0.8 \mathrm{ml}$ of buffer containing $50 \mathrm{mM}$ Tris $\mathrm{Cl} \mathrm{pH} \mathrm{7.4,150} \mathrm{mM} \mathrm{NaCl}$, and $5 \mathrm{mM} \mathrm{KCl}$ for 5-HT and NE transporters; or $50 \mathrm{mM}$ Tris $\mathrm{Cl}$, $\mathrm{pH}$ 7.4, and $100 \mathrm{mM} \mathrm{NaCl}$ for the DA transporter); $\left[{ }^{3} \mathrm{H}\right]$-paroxetine $(0.2 \mathrm{nM}$ final concentration, $25 \mathrm{Ci} / \mathrm{mmol}$, New England Nuclear, Boston, MA), $\left[{ }^{3} \mathrm{H}\right]$-nisoxetine (1.0 nM final concentration, $86 \mathrm{Ci} / \mathrm{mmol}$, New England Nuclear) or $\left[{ }^{3} \mathrm{H}\right]-W i n 35,428(1.0 \mathrm{nM}$ final concentration, $86 \mathrm{Ci}$ / mmol, New England Nuclear) in buffer for the human 5-HT, NE and DA transporters, respectively. Membranes of $10.3 \mu \mathrm{g}, 16.9 \mu \mathrm{g}$ or $6.2 \mu \mathrm{g}$ protein of clonal cells containing human 5-HT, NE and DA transporter, respectively, were added. After incubation, $37^{\circ} \mathrm{C}$ for 40 min for the $5-\mathrm{HT}$ transporter and $25^{\circ} \mathrm{C}$ for $30 \mathrm{~min}$ for $\mathrm{NE}$ and DA transporters, the binding was terminated by rapid vacuum filtration over Whatman GF/B filters (presoaked in $0.5 \%$ polyethylenimine) and the filters were washed four times with cold $50 \mathrm{mM}$ Tris $\mathrm{Cl}$ buffer, $\mathrm{pH}$ 7.4. The filters were then placed in vials containing liquid scintillation fluid and radioactivity was measured by liquid scintillation spectrometry. Non-specific binding was determined by including separate samples of $1 \mu \mathrm{M}$ duloxetine, $10 \mu \mathrm{M}$ desipramine, or $10 \mu \mathrm{M}$ nomifensine, for 5-HT, NE and DA transporters, respectively.

\section{Determination of Binding to Neuronal Receptors}

The binding to human 5-HT receptor subtypes was determined according to published methods $\left(5-\mathrm{HT}_{1 \mathrm{~A}}\right.$ and 5-HT ${ }_{1 \mathrm{E}}$, Zgombick et al. 1991; 5- $\mathrm{HT}_{1 \mathrm{~B}}$ and 5-HT $1 \mathrm{D}$, Weinshank et al. 1992; 5- $\mathrm{HT}_{1 \mathrm{~F}}$, Adham et al. 1993; 5- $\mathrm{HT}_{2 \mathrm{~A}}$, 
5- $\mathrm{HT}_{2 \mathrm{~B}}, 5-\mathrm{HT}_{2 \mathrm{C}}$, Wainscott et al. 1996; 5- $\mathrm{HT}_{6}$, Boess et al. 1997; $5-\mathrm{HT}_{7}$, Bard et al. 1993). The binding to rat $5-\mathrm{HT}_{3}$ receptors was from the method of Wong et al. 1993. Inhibition of binding to $5-\mathrm{HT}_{4}$ and other neuronal receptors was provided by NovaScreen (Hanover, MD).

\section{GTP $\gamma \mathrm{S}$ Binding to $5-\mathrm{HT}_{2}$ Receptors}

Cloned 5- $\mathrm{HT}_{2}$ Receptors. Human cloned 5- $\mathrm{HT}_{2 \mathrm{~A}}, 5-\mathrm{HT}_{2 \mathrm{~B}}$, or $5-\mathrm{HT}_{2 \mathrm{C}}$ receptors were expressed in AV12 cells as described earlier (Lucaites et al. 1996) and frozen until use. Pellets of cells were thawed and washed with assay buffer (excluding GDP), incubated for $10 \mathrm{~min}$ at $37^{\circ} \mathrm{C}$ to hydrolyze any residual 5-HT, washed and suspended for assay (approximately 3-4 $\times 10^{6}$ cell equivalents/well). GTP- $\gamma-\left[{ }^{35} S\right]$ nucleotide exchange Immunoadsorption Scintillation Proximity Assay (ISPA) was conducted as described previously (DeLapp et al. 1999; Conway et al. 1999). Standard assay buffer consisted of $50 \mathrm{mM}$ Tris$\mathrm{HCl}$ (pH 7.4), $100 \mathrm{mM} \mathrm{NaCl}, 10 \mathrm{mM} \mathrm{MgCl}, 0.2 \mathrm{mM}$ EDTA, and $0.1 \mu \mathrm{M}$ GDP. GTP- $\gamma-\left[{ }^{35} \mathrm{~S}\right](1250 \mathrm{Ci} / \mathrm{mmol}$, New England Nuclear), GDP, and agonist and/or antagonist were added to each well of 96-well microtiter plates, with clear bottoms for subsequent SPA counting. Agonist stimulation of the guanyl nucleotide exchange reaction was initiated by the addition of cell membranes with cloned $5-\mathrm{HT}_{2}$ receptors. Plates were mixed and incubated for $30 \mathrm{~min}$ at room temperature. The reaction was quenched by the addition of IGEPAL CA-630 detergent (to final concentration $0.27 \%$ ), primary anti-Gq/11 rabbit polyclonal antibody (Santa Cruz Biotechnology, Santa Cruz, CA; to about $1 \mu \mathrm{g}$ per well), with secondary anti-rabbit SPA beads (Amersham Pharmacia Biotech, Piscataway, NJ) added to each well (about $1.25 \mathrm{mg} /$ well); plates were sealed, mixed, and incubated for $3 \mathrm{~h}$ at room temperature. Finally plates were gently centrifuged, and counted in a Wallac TriLux MicroBeta (Perkin-Elmer, Gaithersburg, $\mathrm{MD})$ scintillation counter.

\section{Microdialysis Experiments}

Animals. Male Sprague-Dawley rats with body weight 260-300 g from Harlan Sprague Dawley (Indianapolis, IN) were used. After acclimatization for at least one week, rats were anesthetized with chloral hydrate/pentobarbital $(170 \mathrm{mg} / \mathrm{kg}$ and $36 \mathrm{mg} / \mathrm{kg}$ in $30 \%$ propylene glycol and $14 \%$ ethanol, respectively) to allow the implantation of dialysis probes.

Probe Implantation. The microdialysis technique has been previously described (Li et al. 1998). Looped dialysis probes were implanted into specific areas of the rat brain and then fixed in place with cranioplastic cement (DuraLay, ordered through BioAnalytical Systems (BAS), West Lafayette, IN). Dialysis probes of loop-type were made using cellulose dialysis membrane (C-D Medical, Miami, FL) with a molecular weight cut-off of $5000 \mathrm{Da}$. The exposed tubing of dialysis probe was $3 \mathrm{~mm}$ length with an outer diameter of $0.6 \mathrm{~mm}$, except for probes implanted into the nucleus accumbens which were $2 \mathrm{~mm}$ in length. The coordinates for specific brain areas were as follows: prefrontal cortex (PFC): A (anterior to bregma) $3.2 \mathrm{~mm}$, L (lateral from the mid-sagittal suture) $-0.8 \mathrm{~mm}, \mathrm{~V}$ (ventral from the dura surface) -5 $\mathrm{mm}$; nucleus accumbens (N Acc): A $2.2 \mathrm{~mm}, \mathrm{~L}-1.5$ $\mathrm{mm}, \mathrm{V}-8 \mathrm{~mm}$; striatum (STR): A $0.2 \mathrm{~mm}, \mathrm{~L}-3 \mathrm{~mm}, \mathrm{~V}$ $-7 \mathrm{~mm}$, hypothalamus (Hypothal): A $-1.5 \mathrm{~mm}, \mathrm{~L}-1.3$ $\mathrm{mm}, \mathrm{V}-9 \mathrm{~mm}$ (all from Paxinos and Watson 1986). Probe location was determined histochemically and rats with improper placement were not included in the statistical analysis.

Microdialysis experiments were performed two days after surgery to allow the rats to fully recover from the operation and resume normal feeding. The rat was placed in a plastic bowl and connected to a fraction collection system for freely moving animals (Raturn, BAS). The input tube of the dialysis probe was connected to a syringe pump (BeeHive and BabyBee, BAS) which delivered an artificial cerebrospinal fluid containing $150 \mathrm{mM}$ $\mathrm{NaCl}, 3 \mathrm{mM} \mathrm{KCl}, 1.7 \mathrm{mM} \mathrm{CaCl}_{2}$ and $0.9 \mathrm{mM} \mathrm{MgCl}_{2}(\mathrm{pH}$ 6.0) to the probe at a rate of $1.0 \mu \mathrm{l} / \mathrm{min}$. The output tubes from the rats were attached to an electrically activated and refrigerated fraction collector (HoneyComb, BAS).

Dialysates were transferred to a refrigerated Gilson Model 231 Autosampler/Injector. Less than 20\% variation of the basal monoamine levels was obtained 2-3 h after the start of experiments. Drugs were given by intraperitoneal (i.p.) injection after at least three stable baseline samples were obtained. Sequential doses were administered i.p. every $90 \mathrm{~min}$.

Assays of Extracellular Monoamine Levels. The sequential dose response study with R-FLX, S-FLX and R,S-FLX was conducted using an on-line system according to the method of Li et al. (1998).

The remainder of the studies were analyzed using an off-line HPLC analytical method that simultaneously detected three monoamines (DA, NE and 5-HT) and the metabolites DOPAC, 5-HIAA and HVA in the same dialysates. A BDS-Hypersil $3 \mu$ C18 analytical column $(2 \times$ $150 \mathrm{~mm}$ from Keystone Scientific, Bellefonte, PA) with a 10-port HPLC valve and a $20 \mu \mathrm{l}$ sample loop was used in configuration with a small sample clean-up column (BDS-Hypersil $3 \mu \mathrm{C} 18,2 \times 10 \mathrm{~mm}$ ) which trapped a late-eluting peak contained in the dialysate samples. The mobile phase for both columns was the same and consisted of $75 \mathrm{mM}$ sodium phosphate monobasic, 350 $\mathrm{mg} / \mathrm{L}$ 1-octanesulfonic acid sodium salt, $0.5 \mathrm{mM}$ EDTA, $0.8 \%$ tetrahydrofuran (HPLC grade, inhibitor-free) and $8 \%$ acetonitrile at $\mathrm{pH} 3$ (adjusted with phosphoric acid). The flow rate for both columns was $0.20 \mathrm{ml} / \mathrm{min}$. The 
analytical column was maintained at $40^{\circ} \mathrm{C}$ with a column heater, while the sample cleanup column was mounted on the 10-port valve at room temperature. An electrochemical detector (EG \& G PARC, Princeton, NJ) with dual glassy carbon electrodes was used $(\mathrm{E} 1=500$ $\mathrm{mV}, \mathrm{E} 2=-50 \mathrm{mV}$, range $=0.5 \mathrm{nA}$ on both electrodes). 5-HT and metabolites were detected at E1 and NE and DA were detected at E2.

The data were collected on three channels using an EZChrom chromatography data system (Scientific Software, San Ramon, CA) running on a Compaq computer that calculated peak heights and sample concentrations. The sensitivity for DA, NE and 5-HT was $0.1 \mathrm{pmol} / \mathrm{ml}$ dialysate or $2 \mathrm{fmol} /$ sample $(20 \mu \mathrm{l})$.

\section{Statistical Analysis}

Binding studies were analyzed with GraphPad Prism software (San Diego, CA) using nonlinear regression analysis on a PC with Microsoft Windows 95 OS. $K_{i}$ values were calculated from $\mathrm{IC}_{50}$ estimates by the method of Cheng and Prusoff (1973). All values for microdialysis studies were calculated as percentage change at each time point compared with the average of three baseline values. Significant differences for the time course of vehicle control injection on NE, DA or 5-HT were determined by a 1-way analysis of variance (ANOVA) for repeated measures with respect to time. Differences between treatment groups, including control, were determined by a 2-way ANOVA with treatment as the independent variable and time as the repeated measure. If significant, the ANOVA was followed by a post-hoc Duncan's multiple range test on the overall effect of treatment using the Statistica program (StatSoft, Tulsa, OK).

Table 1. Inhibition of Binding to Human Monoamine Transporters by Fluoxetine, Norfluoxetine and Other Antidepressants

\begin{tabular}{lccc}
\hline & \multicolumn{3}{c}{ Transporter } \\
\cline { 2 - 4 } Compound & $\mathbf{5 - H T}$ & NE & DA \\
\hline & & $\mathrm{K}_{\mathrm{i}}, \mathrm{nM}$ & \\
R-fluoxetine & $7.7 \pm 1.0$ & $>10000$ & $>10000$ \\
R-norfluoxetine & $68 \pm 12$ & $>10000$ & $>10000$ \\
S-fluoxetine & $6.1 \pm 0.3$ & $>10000$ & $>10000$ \\
S-norfluoxetine & $4.8 \pm 0.3$ & $>10000$ & $>10000$ \\
R,S-fluoxetine & $6.9 \pm 0.6$ & $1021 \pm 46$ & $4752 \pm 44$ \\
R,S-norfluoxetine & $9.9 \pm 0.5$ & $>10000$ & $>10000$ \\
Citalopram & $9.5 \pm 1.3$ & $>10000$ & $>10000$ \\
Fluvoxamine & $10 \pm 1.4$ & $>10000$ & $>10000$ \\
Paroxetine & $0.38 \pm 0.04$ & $132 \pm 6.8$ & $393 \pm 53$ \\
Sertraline & $0.9 \pm 0.2$ & $715 \pm 53$ & $26 \pm 1.7$ \\
Desipramine & $179 \pm 10$ & $3.8 \pm 0.3$ & $>10000$ \\
Imipramine & $19 \pm 0.9$ & $98 \pm 4$ & $>10000$ \\
\hline
\end{tabular}

Compounds were evaluated with 7-11 concentrations in triplicate and data are from at least three separate experiments.

\section{RESULTS}

\section{Transporter and Receptor Binding Studies}

R-FLX inhibited binding of $\left[{ }^{3} \mathrm{H}\right]$-paroxetine binding to membranes from HEK 293 cells transfected with human 5-HT transporters with a $K_{i}$ value of $7.7 \pm 1.0 \mathrm{nM}$, but did not appreciably inhibit binding to human NE or DA transporters (Table 1). R,S-FLX, S-FLX, R,S-norfluoxetine and S-norfluoxetine had similar affinity for the human 5-HT transporter as R-FLX had low affinity for the NE and DA transporters. However, R-norfluoxetine had lower affinity for the 5-HT transporter than R-FLX. Other SSRIs such as citalopram, fluvoxamine, paroxetine and sertraline also had high affinity for the 5-HT transporter and relatively low affinity for the NE and DA transporters. Of the drugs tested, paroxetine had the highest affinity for the serotonin transporter. Imipramine inhibited binding to both the 5-HT and NE transporters, whereas desipramine, a NE uptake inhibitor, had higher affinity for NE than 5-HT transporters.

The affinity of FLX, the enantiomers of FLX and R-norfluoxetine was determined for a number of serotonin receptor subtypes (Table 2). R-FLX and R-norfluoxetine had $K_{i}$ values of $68 \pm 1$ and $115 \pm 10 \mathrm{nM}$, respectively, for human $5-\mathrm{HT}_{2 \mathrm{~A}}$ receptors and $\mathrm{K}_{\mathrm{i}}$ values of $70 \pm 8$ and $116 \pm 5 \mathrm{nM}$ for $5-\mathrm{HT}_{2 \mathrm{C}}$ receptors, respectively. S-FLX had greater than 20 -fold lower affinity for $5-\mathrm{HT}_{2 \mathrm{~A}}$ and $5-\mathrm{HT}_{2 \mathrm{C}}$ receptors than $\mathrm{R}$-fluoxetine. The compounds did not have appreciable affinity for the other 5-HT receptor subtypes investigated. In a comparison of the affinity of $\mathrm{R}-\mathrm{FLX}$ on binding affinity to the human and rat $5-\mathrm{HT}_{2 \mathrm{~A}}$ receptors, it was found that R-FLX had significantly lower affinity for the rat than human $5-\mathrm{HT}_{2 \mathrm{~A}}$ receptor subtype, with $\mathrm{K}_{\mathrm{i}}$ values of $165 \mathrm{nM}$ (data not shown).

Table 2. Inhibition of Radioligand Binding to Human Serotonin Receptor Subtypes by R,S-fluoxetine, S-fluoxetine, $\mathrm{R}$-fluoxetine and R-norfluoxetine

\begin{tabular}{lcccc}
\hline Receptor & FLX & S-FLX & R-FLX & R-NFLX \\
\hline \multicolumn{4}{c}{$\mathrm{K}_{\mathrm{i}}, \mathrm{nM}$} \\
$5-\mathrm{HT}_{1 \mathrm{~A}}$ & $>5000$ & 4045 & 3462 & 3766 \\
$5-\mathrm{HT}_{1 \mathrm{~B}}$ & $>5000$ & 3910 & 2892 & 4080 \\
$5-\mathrm{HT}_{1 \mathrm{D}}$ & $>5000$ & 4547 & 4525 & $>5000$ \\
$5-\mathrm{HT}_{1 \mathrm{E}}$ & $>5000$ & $>5000$ & $>5000$ & $>5000$ \\
$5-\mathrm{HT}_{1 \mathrm{~F}}$ & 4955 & 4580 & 4659 & 4971 \\
$5-\mathrm{HT}_{2 \mathrm{~A}}$ & $119 \pm 10$ & $1409 \pm 120$ & $68 \pm 1$ & $115 \pm 10$ \\
$5-\mathrm{HT}_{2 \mathrm{~B}}$ & 2514 & 3189 & 4180 & $>5000$ \\
$5-\mathrm{HT}_{2 \mathrm{C}}$ & $118 \pm 11$ & $2390 \pm 310$ & $70 \pm 8$ & $116 \pm 5$ \\
$5-\mathrm{HT}_{3}$ & 19000 & $>10000$ & 11000 & 4000 \\
$5-\mathrm{HT}_{4}$ & 788 & 1074 & 2767 & 2088 \\
$5-\mathrm{HT}_{6}$ & 1038 & $2730 \pm 194$ & $591 \pm 33$ & $2450 \pm 120$ \\
$5-\mathrm{HT}_{7}$ & $>5000$ & 3397 & 4898 & $>5000$ \\
\hline
\end{tabular}

Binding data is to human receptors, except for $5 \mathrm{HT}_{3}$ data which is from rat (Wong et al. 1993.) Data is from triplicate determination from three separate experiments with 7-11 concentrations of the drugs. (FLX = fluoxetine, NFLX = norfluoxetine) 
Table 3. Agonist and Antagonist Activity of R-fluoxetine at Human $5 \mathrm{HT}_{2}$ Cloned Receptors Using GTP $\gamma \mathrm{S}$ Binding with $\mathrm{G}_{\mathrm{q}}$ Antibody Capture

\begin{tabular}{lcc}
\hline Receptor & \% Max of Full Agonist & $\mathbf{K}_{\mathbf{I}}, \mathbf{n M}$ \\
\hline $5-\mathrm{HT}_{2 \mathrm{~A}}$ & $-10 \pm 4$ & $193(107-346)$ \\
$5-\mathrm{HT}_{2 \mathrm{~B}}$ & $2 \pm 6$ & $>10000$ \\
$5-\mathrm{HT}_{2 \mathrm{C}}$ & $-1 \pm 5$ & $493(255-953)$ \\
\hline
\end{tabular}

$\%$ max of full agonist refers to $\%$ of maximal stimulation obtained with $10 \mu \mathrm{M} 5-\mathrm{HT}$. The $\mathrm{K}_{\mathrm{i}}$ values refer to inhibition constants obtained by blocking 5-HT-stimulated GTP $\gamma \mathrm{S}$ binding at $100 \mathrm{nM}$ for $5-\mathrm{HT}_{2 \mathrm{~A}}$ and $5-\mathrm{HT}_{2 \mathrm{~B}}$ and $10 \mathrm{nM}$ for $5-\mathrm{HT}_{2 \mathrm{C}}$ receptors. ( $\mathrm{n}=4-7$ separate determinations)

R-FLX did not stimulate GTP $\gamma S$ binding to the G protein $\mathrm{Gq}$ in cell lines transfected with $5-\mathrm{HT}_{2 \mathrm{~A}}$ and $5-\mathrm{HT}_{2 \mathrm{C}}$ receptors, indicating a lack of agonist activity (Table 3). However, R-FLX antagonized 5-HT (100 nM and 10 $\mathrm{nM}$ ) stimulated GTP $\gamma \mathrm{S}$ binding in cell lines transfected with 5- $\mathrm{HT}_{2 \mathrm{~A}}$ and $5-\mathrm{HT}_{2 \mathrm{C}}$ receptors, respectively. The inhibition constants $\left(\mathrm{K}_{\mathrm{i}}\right)$ of R-FLX for blocking 5-HT stimulated ${ }^{35}$ S-GTP $\gamma S$ binding in cell lines were $193 \mathrm{nM}$ and $493 \mathrm{nM}$ for the $5-\mathrm{HT}_{2 \mathrm{~A}}$ and $5-\mathrm{HT}_{2 \mathrm{C}}$ receptors, respectively (Table 3 ). In contrast, S-FLX did not block 5-HT stimulated GTP $\gamma S$ binding in cell lines transfected with $5-\mathrm{HT}_{2 \mathrm{~A}}$ and $5-\mathrm{HT}_{2 \mathrm{C}}$ receptors up to concentrations of 10 $\mu \mathrm{M}$ (data not shown).

\section{Microdialysis Experiments}

Basal levels of the monoamines in different brain regions, expressed in $\mathrm{pmol} / \mathrm{ml}$ are shown in Table 4 . Vehicle administration did not alter monoamine levels in the PFC (Figure 1, panel A) with respect to time as shown by a 1-way ANOVA with repeated measures $\left(\mathrm{F}_{8,40}=0.399,2.090\right.$ and 0.681 for NE, DA and 5-HT respectively). Vehicle controls in other brain regions were also not significantly changed (data not shown).

Effect of Fluoxetine Enantiomers on Extracellular Levels of Prefrontal Cortex 5-HT, NE, and DA. R-, S- or R,S-FLX were administered sequentially i.p. at 3, 10, and $20 \mathrm{mg} /$ kg 90 min apart. The three compounds similarly and significantly increased 5-HT extracellular levels in prefrontal cortex at $3 \mathrm{mg} / \mathrm{kg}$ up to $211-224 \%$ of basal levels and the $10 \mathrm{mg} / \mathrm{kg}$ dose produced greater increases to $386 \%$ of basal levels. The 2-way ANOVA indicated that there was a significant effect of all compounds $\left(\mathrm{F}_{9,117}=\right.$ $26.22, p<.001$ ), Figure 1, panel B. However, the 20-mg/ $\mathrm{kg}$ dose did not produce appreciably greater increases, indicating that $10 \mathrm{mg} / \mathrm{kg}$ gives maximal 5-HT extracellular increases. There was no significant difference at any dose between the effect of FLX, R-FLX and S-FLX on extracellular 5-HT levels $\left(\mathrm{F}_{18,117}=0.796\right.$ with respect to dose-treatment interaction).

The extracellular levels of DA in prefrontal cortex were not significantly increased at $3 \mathrm{mg} / \mathrm{kg}$ by the compounds (Figure 1, panel C). However, the R-FLX 10$\mathrm{mg} / \mathrm{kg}$ i.p. sequential dose at $90 \mathrm{~min}$ significantly increased DA extracellular levels to $273 \pm 38 \%$ of basal levels, whereas S-FLX and R,S-FLX increased DA extracellular levels to about $170 \%$ of basal levels . The R-FLX 20-mg/kg sequential dose further increased extracellular levels of DA to over $600 \%$ of basal levels. The $20-$ $\mathrm{mg} / \mathrm{kg}$ sequential dose of S-fluoxetine and R,S-fluoxetine increased extracellular levels of DA up to about 254 and $372 \%$ of basal levels, respectively. The 2-way ANOVA on overall effects revealed that there was a significant effect of treatment $\left(\mathrm{F}_{2,13}=8.55, p<.005\right)$ and dose $\left(\mathrm{F}_{9,117}=34.23, p<.001\right)$ and dose-treatment interaction $\left(\mathrm{F}_{18,117}=3.63, p<.001\right)$. Thus, R-FLX produced significantly larger increases of extracellular levels of DA than S-FLX $(p<.002)$ or RS-FLX $(p<.01)$ according to a post-hoc Duncan's test.

As found with DA, the $3-\mathrm{mg} / \mathrm{kg}$ dose of the compounds did not significantly alter extracellular levels of NE in prefrontal cortex (Figure 1, panel D). However, R-fluoxetine significantly increased extracellular levels of NE up to 211 and $323 \%$ after administration of the sequential doses of 10 and $20 \mathrm{mg} / \mathrm{kg}$ i.p. Administration of the sequential doses of S-FLX and R,S-FLX produced smaller peak increases in the extracellular levels of $\mathrm{NE}$ up to $149 \%$ and $257 \%(10 \mathrm{mg} / \mathrm{kg}$ ) and $256 \%$ and $298 \%$ (20 mg/kg), respectively Although the 2-way ANOVA showed a significant effect of dose $\left(\mathrm{F}_{9,117}=41.15, p<\right.$ $.001)$, there was no significant difference in treatments $\left(\mathrm{F}_{2,13}=1.16\right)$.

Administration of R-FLX (3, 10 and $30 \mathrm{mg} / \mathrm{kg}$ i.p.) administered in single doses increased extracellular levels of 5-HT dose dependently. For comparisons, a 4-h average post drug treatment value was calculated with increases of $138 \%, 349 \%$, and $338 \%$ of basal levels, respectively (Figure 2). A post-hoc Duncan's test showed

Table 4. Basal Levels of the Monoamines in Different Brain Regions

\begin{tabular}{lcccc}
\hline Monoamine & Prefrontal Cortex & Hypothalamus & Striatum & Nucleus Accumbens \\
\hline & \multicolumn{4}{c}{$\mathrm{pmol} / \mathrm{ml}$} \\
$5-\mathrm{HT}$ & $0.19 \pm 0.04$ & $0.30 \pm 0.04$ & $0.25 \pm 0.1$ & $0.18 \pm 0.06$ \\
NE & $0.70 \pm 0.25$ & $0.80 \pm 0.25$ & $\mathrm{n} / \mathrm{a}$ & $1.0 \pm 0.4$ \\
DA & $0.30 \pm 0.1$ & $0.26 \pm 0.05$ & $5.8 \pm 0.7$ & $4.5 \pm 1.6$ \\
\hline
\end{tabular}

$\mathrm{n} / \mathrm{a}=$ not available 

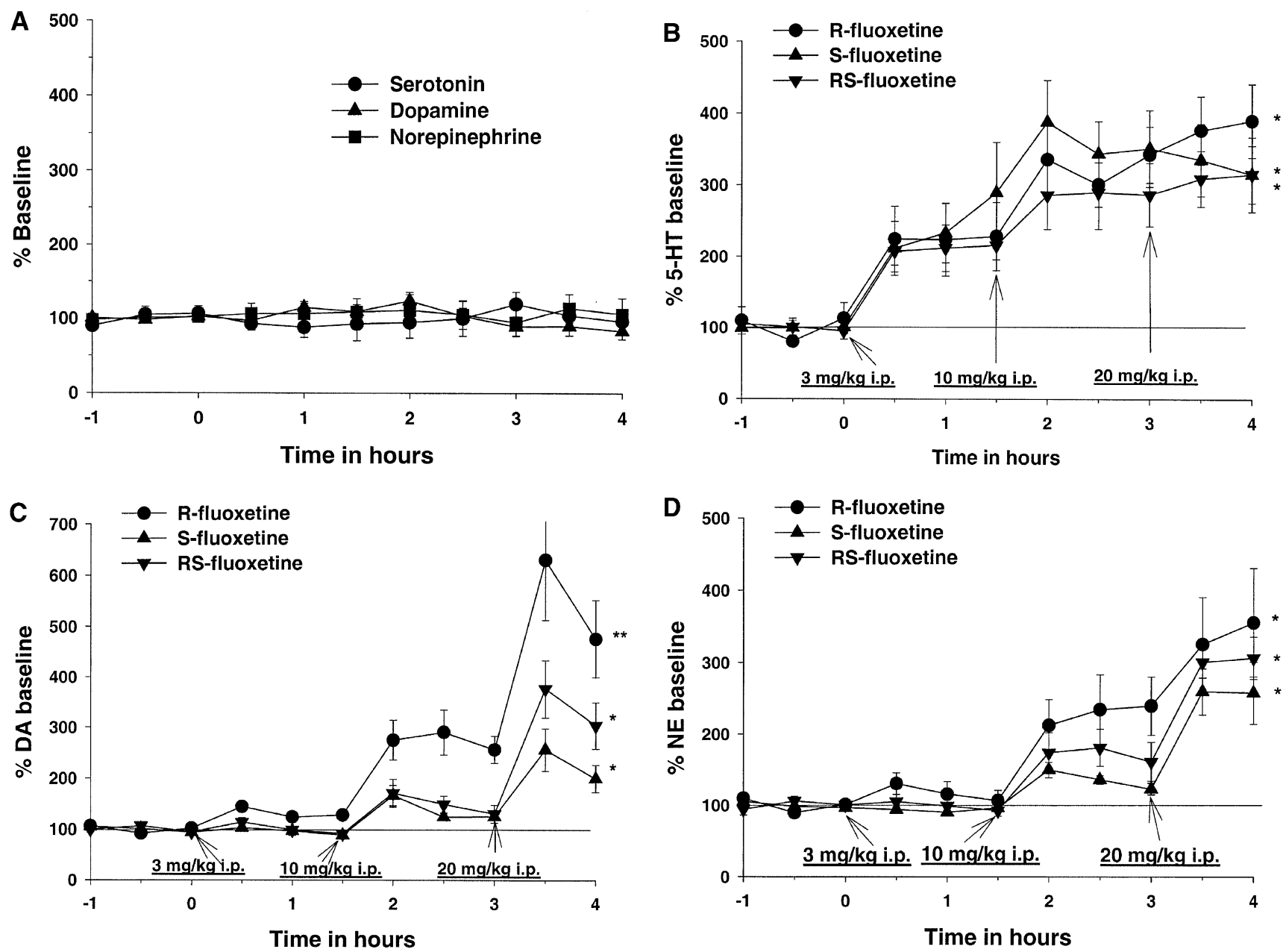

Figure 1. Effect of vehicle injection on levels of extracellular monoamines (A) and R-, S-, and R,S-fluoxetine on extracellular levels of 5 -HT ((B) ${ }^{*} p<.001$ vs. control), dopamine $(\mathbf{C}){ }^{*} p<.01$ vs. control, ${ }^{* *} p<.01$ vs. RS or S-fluoxetine), and norepinephrine ((D) $p<.001$ vs. control) in prefrontal cortex of conscious rats. Drugs were administered sequentially at $0,1.5$, and $3 \mathrm{~h}$ with doses of 3,10 , and $20 \mathrm{mg} / \mathrm{kg}$ i.p., as indicated by the arrows. Values are the mean \pm SEM of the \% of pre-drug baseline concentration determined at $-1,-0.5$, and $0 \mathrm{~h}$.

that the 3-mg/ $\mathrm{kg}$ dose was not significantly different from control $(p<.29)$ but the 10 and $30-\mathrm{mg} / \mathrm{kg}$ doses were significantly different $(p<.001)$. At the lowest dose R-FLX did not significantly alter extracellular levels of DA, but significantly increased the 4-h average at 10 and $30 \mathrm{mg} / \mathrm{kg}$ i.p. to $165 \%$ and $231 \%$ of basal, respectively (post-hoc Duncan's test, $p<.006$ ). Administration of $3 \mathrm{mg} / \mathrm{kg}$ R-FLX did not significantly increase extracellular levels of NE, but the 10 and $30-\mathrm{mg} / \mathrm{kg}$ dose increased the 4 -h average to $200 \%$ and $405 \%$ of basal levels, respectively (post-hoc Duncan's test, $p<.002$ ).

Effect of R-FLX on Extracellular 5-HT, NE and DA in Prefrontal Cortex, Hypothalamus Nucleus Accumbens, and Striatum. The effect of R-FLX (10 mg/ kg i.p.) on extracellular levels of monoamine was investigated in prefrontal cortex, hypothalamus, nucleus accumbens and striatum. To determine statistical significance the overall effect (4-h average) was compared with the appropriate control (values not shown) using a 2-way ANOVA and subsequent Duncan's test, if warranted. All $p$ values given below are from the Duncan's test. In the prefrontal cortex, R-FLX increased 5-HT, DA and NE extracellular levels to 4 -h averages of $349 \pm 2 \%(p<$ $.001), 165 \pm 5 \%(p<.03)$ and $200 \pm 8 \%(p<.007)$, respectively of basal levels (Figure 3, panel A). Extracellular 5-HT, DA and NE levels in the hypothalamus were increased by R-FLX administration with 4-h averages of $239 \pm 15 \%(p<.002), 176 \pm 17 \%(p<.001)$ and $237 \pm$ $30 \%(p<.002)$, respectively (Figure 3 , panel B). The administration of R-FLX increased the 4-h average of extracellular 5-HT and DA levels in the nucleus accumbens to $211 \pm 12 \%(p<.003)$ and $108 \pm 2 \%\left(F_{1,10}=0.33\right.$, non-significant) and, respectively (Figure 3 , panel C). In the striatum, R-FLX increased the 4-h average of 5-HT and DA extracellular levels to $427 \pm 34 \%(p<.001)$ and 


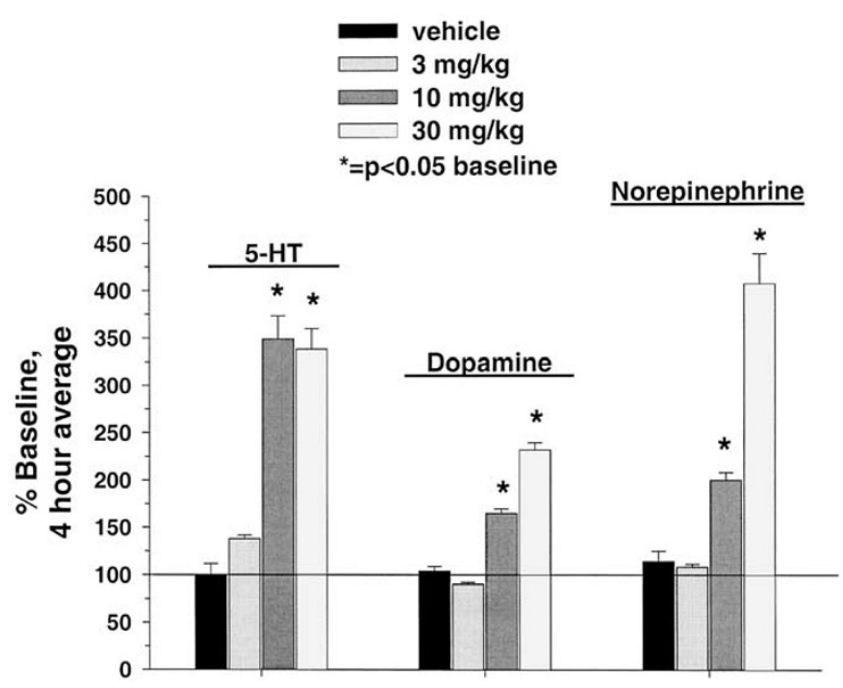

Figure 2. Dose-dependent increase of extracellular levels of serotonin $(5-\mathrm{HT})$, dopamine and norepinephrine produced by R-fluoxetine in the prefrontal cortex of conscious rats. Data are expressed in \% baseline for a 4-h average increase. Values are the mean \pm SEM of the \% of pre-drug baseline concentration determined at $-1,-0.5$, and $0 \mathrm{~h}(p<$ .01 vs. control).

$132 \pm 2 \%(p<.02)$, respectively (Figure 3, panel D). The NE levels were too low and variable to reliably quantitate in the nucleus accumbens or striatum.

\section{DISCUSSION}

The above studies demonstrate the unique binding properties and monoamine interactions of R-FLX, one of the two stereoisomers of FLX (Prozac). R-FLX and S-FLX have similar affinity for the human 5-HT transporter and low affinity for the DA and NE transporters. Similar affinity of the enantiomers for 5-HT uptake has been found in studies utilizing monoamine uptake in rat synaptosomes (Wong et al. 1993). However, stereoselectivity for human $5-\mathrm{HT}_{2 \mathrm{~A}}$ and $5-\mathrm{HT}_{2 \mathrm{C}}$ receptors was found for R-FLX versus S-FLX with R-FLX having at least 20-fold higher affinity for the two receptors than SFLX. R-FLX had $\mathrm{K}_{\mathrm{i}}$ values for 5- $\mathrm{HT}_{2 \mathrm{~A}}$ and $5-\mathrm{HT}_{2 \mathrm{C}}$ receptors of 68 and $70 \mathrm{nM}$, respectively; this affinity was likely high enough to block these receptors in vivo, as FLX $(10 \mathrm{mg} / \mathrm{kg})$ had drug levels of $242 \mathrm{nM}$ concentration in PFC (Bymaster et al. 2002). It has been previously reported that $\mathrm{R}, \mathrm{S}$-fluoxetine had moderate affinity for animal 5- $\mathrm{HT}_{2 \mathrm{C}}$ receptors (formerly called 5-HT1C) (Wong et al. 1995; Pälvimäki et al. 1996). Functional studies indicated that R-FLX was an antagonist at $5-\mathrm{HT}_{2 \mathrm{~A}}$ and $5-\mathrm{HT}_{2 \mathrm{C}}$ receptors. Human monoamine transporter binding studies by Owens et al. (2001) confirmed the selectivity of R-FLX for the human serotonin transporter and $5-\mathrm{HT}_{2 \mathrm{C}}$ receptors.
Stereoselective differences for R-FLX and S-FLX were also found in microdialysis studies in the rat prefrontal cortex. R-FLX and S-FLX produced similar increases in extracellular levels in 5-HT, but at the same dose R-FLX produced significantly greater increases in extracellular DA and NE levels. The racemic mixture, R,S-FLX, produced intermediate increases in the extracellular levels of DA and NE compared with R-FLX and S-FLX. Among SSRIs, fluoxetine uniquely increases extracellular levels of DA and NE as well as 5-HT (Pozzi et al. 1999; Bymaster et al. 2002). We have previously shown that R,S-FLX increases NE extracellular levels robustly in the hypothalamus (Perry and Fuller 1997). These data suggest that the elevation of DA and NE produced by R,S-FLX are predominantly mediated by R-FLX.

Since R-fluoxetine produced robust increases in extracellular 5-HT levels as well as DA and NE, the dosedependent increases in extracellular monoamines produced by R-fluoxetine in prefrontal cortex were investigated in single dose studies. At $3 \mathrm{mg} / \mathrm{kg}$ i.p., R-FLX only increased 5-HT extracellular levels, but at 10 and $30 \mathrm{mg} / \mathrm{kg}$ i.p., the extracellular levels of DA and NE were also robustly increased. In microdialysis studies in various brain regions, R-FLX at $10 \mathrm{mg} / \mathrm{kg}$ i.p. was effective in increasing extracellular levels of 5-HT and NE in all brain areas examined, except the striatum and nucleus accumbens, where we were unable to measure NE levels. The elevation of 5-HT levels was greatest in the prefrontal cortex and striatum. The extracellular levels of NE in the hypothalamus increased to a greater extent than 5-HT for $1.5 \mathrm{~h}$ after drug administration. Extracellular levels of DA were significantly elevated in the prefrontal cortex and hypothalamus, but were not appreciably elevated in the dopamine-rich nucleus accumbens and striatum.

The mechanism by which R-FLX increases extracellular levels of DA and NE is not clear. Acute administration of SSRIs such as citalopram, paroxetine and fluvoxamine increases extracellular levels of 5-HT, but not DA and NE (Pozzi et al. 1999; Jordan et al. 1994; Bymaster et al. 2002), thus suggesting that the catecholamine increases are not mediated by increased extracellular levels of 5-HT. Furthermore, R-FLX was shown in the present study to have low affinity for NE and DA transporters, suggesting the increases are not due to nonselective blockade of catecholamine transporters. However, the demonstrated antagonism with $5-\mathrm{HT}_{2 \mathrm{~A}}$ and $5-\mathrm{HT}_{2 \mathrm{C}}$ receptors by R-FLX may be involved in the increased levels of catecholamines, particularly in cortical areas. The other major SSRIs, citalopram, fluvoxamine, paroxetine and citalopram, do not have significant affinity for human 5- $\mathrm{HT}_{2 \mathrm{~A}}$ and $5-\mathrm{HT}_{2 \mathrm{C}}$ receptors, (Jenck et al. 1993; Pälvimäki et al. 1996, Owens et al. 1997). The interactions at these receptors may be responsible for the robust elevations of both DA and NE in the prefrontal cortex produced by R-FLX. This finding is in agreement 

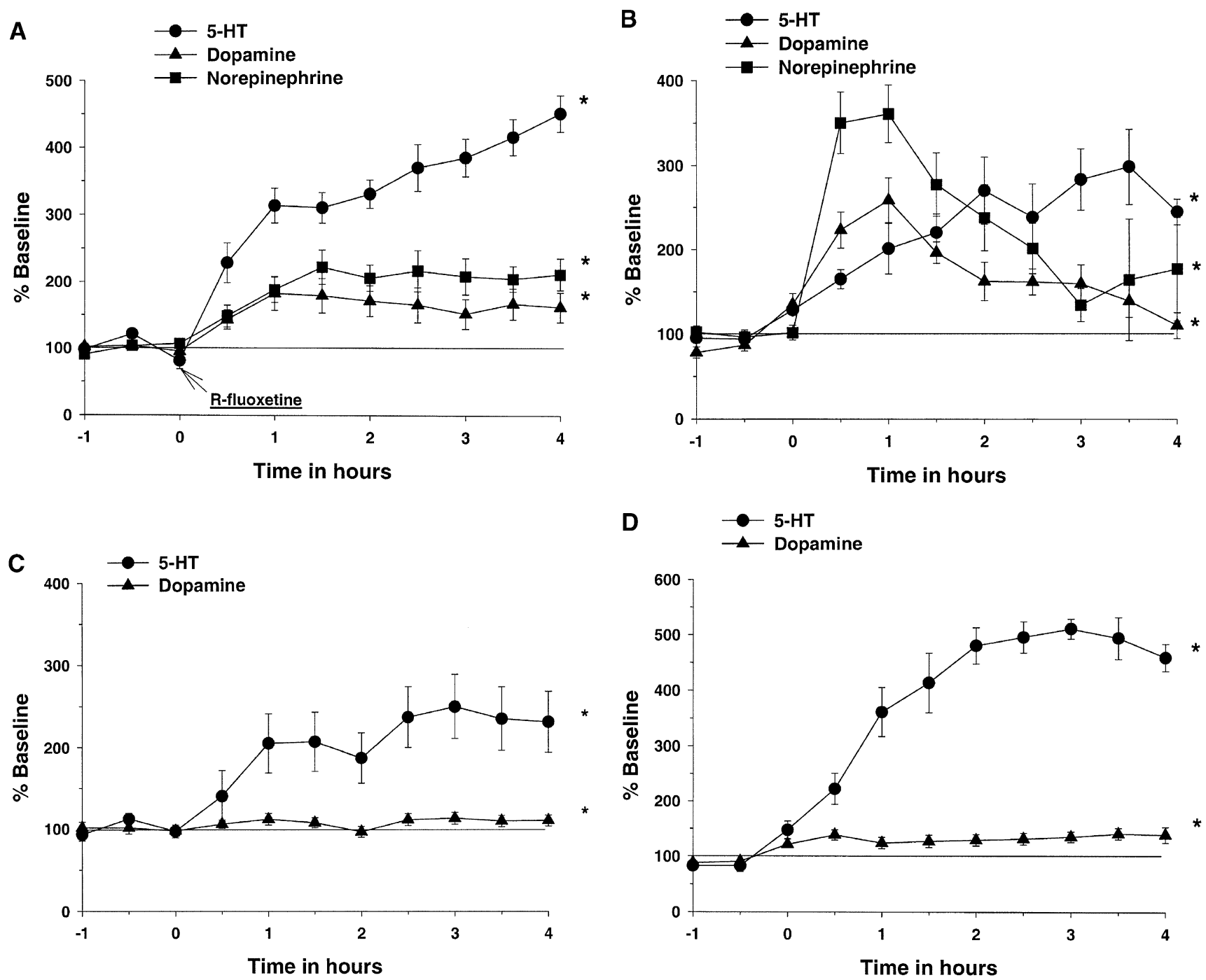

Figure 3. Effect of R-FLX on extracellular monoamine levels in the prefrontal cortex, ((A) * $p<.03)$, hypothalamus $\left(\mathbf{( B )}{ }^{*} p<\right.$ $.002)$, nucleus accumbens $\left(\mathbf{( C )}{ }^{*} p<.003\right)$, and striatum of conscious rats ((D) $\left.{ }^{*} p<.02\right)$. Data are expressed as $\%$ baseline concentrations and drug was administered at time zero. Statistical significance was determined by calculating the overall effect (4-h average) of the drug.

with a study by Millan et al. (1998), showing that a $5-\mathrm{HT}_{2 \mathrm{C}}$ receptor antagonist elevated both $\mathrm{DA}$ and $\mathrm{NE}$ levels in the prefrontal cortex, whereas an agonist decreased extracellular DA and NE. Furthermore, fluoxetine $(10$ and $20 \mathrm{mg} / \mathrm{kg}$ ) has been shown to have in vivo occupancy of the $5-\mathrm{HT}_{2 \mathrm{C}}$ receptors in rat choroid plexus (Pälvimäki et al. 1999), suggesting that R-FLX may block $5-\mathrm{HT}_{2 \mathrm{C}}$ receptors in vivo. However, other mechanisms may be involved since S-FLX also increased NE and DA to some extent in the prefrontal cortex in spite of low affinity for $5-\mathrm{HT}_{2 \mathrm{C}}$ receptors. The results in the nucleus accumbens, however, are in contrast to the findings by Di Matteo at al. (2000), who found increased DA release in the nucleus accumbens after blocking $5-\mathrm{HT}_{2 \mathrm{C}}$ receptors. The sensitivity and distribution of $5-\mathrm{HT}_{2}$ receptors within the nucleus accumbens may account for these differences. A report by Bowers et al. (2000) demonstrates that $5-\mathrm{HT}_{2}$ receptor stimulation by DOI elevates DA only in the posterior nucleus accumbens; however, no reference is made to the specific receptor subtype involved.

The PFC is a region of interest due to the fact that depressed patients have reduced metabolism in the PFC as well as other anterior cortical regions, indicating an abnormality in these brain regions (Baxter et al. 1989; Rubin et al. 1995). Histopathological studies of post mortem brain tissues from depressed patients showed decreased size of neurons in prefrontal cortical regions such as dorsolateral PFC (Rajkowska et al. 1999). Further, the PFC is a complex collection of neural systems with extensive afferents of serotonergic, dopamine and noradrenergic neurons (Lindvall and Bjorklund 1978, 
1983; Van Bockstaele et al. 1993), suggesting the potential for interactions and synergistic effects of the monoamines. Given the success of antidepressants aimed at elevating the monoamines, elevating NE and DA as well as serotonergic neurotransmission in the PFC likely plays a role in depression therapy.

These data suggest that the novel pharmacologic effects of R-FLX may provide added benefits in aiding development of new potential antidepressant compounds. In addition to increases of extracellular NE and DA concentrations in prefrontal cortex and other brain regions, the side effect profile of R-FLX-like compounds may also be improved through its blockade of the $5-\mathrm{HT}_{2 \mathrm{~A}}$ receptor, which mediates sleep disturbances, sexual dysfunction and anxiety (Pullar et al. 2000). Indeed, blockade of the $5-\mathrm{HT}_{2}$ receptor can reverse sexual dysfunction and antidepressants with $5-\mathrm{HT}_{2}$ affinity do not induce sexual dysfunction (Stein and Hollander 1994; Balon 1997). Two other antidepressants, nefazodone and trazodone, share this property of potent antagonism of the $5-\mathrm{HT}_{2 \mathrm{~A}}$ receptor (Cusack et al. 1994). Interestingly, the dopaminergic activity of R-FLX like compounds may also be advantageous in this respect since bupropion does not cause sexual dysfunction, but can alleviate this side effect caused by SSRIs (Stein and Hollander 1994; Balon 1997).

Interesting to note is the fact that 5-HT neuronal firing rates in the raphe recover much faster following chronic R-FLX application compared with racemic FLX (Lodge and Webb 2000). Acute administration of SSRIs decrease the firing rate of dorsal raphe neurons, presumably due to activation of $5-\mathrm{HT}_{1 \mathrm{~A}}$ somatodendritic inhibitory autoreceptors which results in decreased release of 5-HT (Chaput et al. 1986; Czachura and Rasmussen 2000). In vivo microdialysis studies showed different effects of acutely versus repeatedly applied SSRIs on the release of 5-HT in the cell body area versus terminal fields. It was shown that acute doses of SSRIs preferentially increased 5-HT in the raphe rather than in projection fields (fluvoxamine, Bel and Artigas 1992; citalopram, Invernizzi et al. 1992; fluoxetine, Malagie et al. 1995; paroxetine, Gartside et al. 1995). However, there are also reports that acute SSRIs do elevate monoamines, particularly 5-HT, in certain projection fields (Perry and Fuller 1997; Pozzi et al. 1999; Bymaster et al. 2002), this effect, however, is blunted by acute autoreceptor stimulation. Unlike transporter substrates that reverse the action of the transporter irrespective of impulse flow, the SSRIs are dependent on the presence of newly released neurotransmitter to have an active effect. The clinical response has been hypothesized to be delayed until gradual desensitization of the $5-\mathrm{HT}_{1 \mathrm{~A}}$ autoreceptors takes place (Artigas 1993; Blier and de Montigny 1994); however, agents that allow faster recovery of raphe firing, like R-FLX, may have a more rapid onset.

Thus, R-FLX robustly increases extracellular levels of $5-\mathrm{HT}, \mathrm{NE}$, and DA in the prefrontal cortex, which is unique for SSRIs (Richelson 1996). Given the diverse symptomatology of depression and the clinical success of agents acting on all three monoamine systems, pharmaceutical agents with the properties like R-FLX represent a potential major improvement for treatment strategies. Increases in extracellular DA and NE levels, in addition to elevating 5-HT levels, may be very efficient in the treatment of certain types of depression. Selectivity for certain receptor subtypes will alleviate bothersome side effects, and may also shorten the onset to a clinical recovery. More research on 5-HT receptor subtypes and the regulation of interaction between the 5-HT, $\mathrm{NE}$ and DA systems is warranted to improve the efficacy of currently available treatments for depression.

\section{REFERENCES}

Adham N, Kao HT, Schecter LE, Bard J, Olsen M, Urquhart D, Durkin M, Hartig PR, Weinshank RL, Branchek TA (1993): Cloning of another human serotonin receptor (5HT1F): a fifth 5-HT1 receptor subtype coupled to the inhibition of adenylate cyclase. Proc Natl Acad Sci USA 90:408-412

Artigas F (1993): Serotonin and antidepressants: New views from microdialysis studies. Trends Pharmacol Sci 14: 262

Atre-Vaidya N, Jampala VC (1988): Electroconvulsive therapy in parkinsonism with affective disorder. Br J Psychiatry 152:55-58

Balon R (1997): The effects of antidepressants on human sexuality: diagnosis and management update 1996. Primary Psychiatry 4:32-48

Bard JA, Zgombick J, Adham N, Vaysse P, Branchek TA, Weinshank RL (1993): Cloning of a novel human serotonin receptor (5-HT7) positively linked to adenylate cyclase. J Biol Chem 268:23422-23426

Baxter LR Jr, Schwartz JM, Phelps ME, Mazziotta JC, Guze BH, Selin CE, Gerner RH, Sumida RM (1989): Reduction of prefrontal cortex glucose metabolism common to three types of depression. Arch Gen Psychiatry 46:243-250

Bel N, Artigas F (1992): Fluvoxamine preferentially increases extracellular 5-hydroxytryptamine in the raphe nuclei: an in vivo microdialysis study. Eur J Pharmacol 229: 101-103

Berk M, du Plessis AD, Birkett M and Richardt D, on behalf of the Lilly Duloxetine Depression Study Group (1997): An open-label study of duloxetine hydrochloride, a mixed serotonin and noradrenaline reuptake inhibitor, in patients with DSM-III-R major depressive disorder. Int Clin Psychopharmacology 12:137-140

Blier P, de Montigny C (1994): Current advances and trends in the treatment of depression. Trends Pharmacol Sci $15: 220-225$

Boess FG, Monsma FJ Jr, Carolo C, Meyer V, Rudler A, Zwingelstein C, Sleight AJ (1997): Functional and radioligand binding characterization of rat 5-HT6 receptors stably expressed in HEK293 cells. Neuropharmacology 36:713-720 
Bourin M, Baker GB (1996): The future of antidepressants. Biomed Pharmacother 50:7-12

Bowers BJ, Henry MB, Thielen RJ, McBride WJ (2000): Serotonin 5-HT(2) receptor stimulation of dopamine release in the posterior but not anterior nucleus accumbens of the rat. J Neurochem 75:1625-1633

Brown AS, Gershon S (1993): Dopamine and depression. J Neural Transm 91:75-109

Bymaster FP, Zhang W, Carter PA, Shaw J, Chernet E, Phebus L, Wong DT, Perry KW (2002): Fluoxetine, but not other selective serotonin reuptake inhibitors, increases norepinephrine and dopamine extracellular levels in the prefrontal cortex. Psychopharmacology 160:353-361

Chaput Y, de Montigny C, Blier P (1986): Effects of a selective 5-HT reuptake blocker, citalopram, on the sensitivity of 5-HT autoreceptors: Electrophysiological studies in the rat brain. Naunyn-Schmiedeberg's Arch Pharmacol 333:342-348

Cheng YC, Prusoff WH (1973): Relationship between the inhibition constant $\left(\mathrm{K}_{\mathrm{i}}\right)$ and the concentration of inhibitor which causes a 50 percent inhibition $\left(\mathrm{IC}_{50}\right)$ of an enzymatic reaction. Biochem Pharmacol 22:3090-3108

Conway R, DeLapp N, Lucaites V, Wainscott DB, Nelson DL (1999): Cloned human 5- $\mathrm{HT}_{2 \mathrm{~A}},-2 \mathrm{~B}$, and ${ }_{-2 \mathrm{C}}$ receptor activation of GTP- $\square-\left[{ }^{35} \mathrm{~S}\right]$ binding to specific $\mathrm{G}$ proteins $(\mathrm{Gq}$ or Gi) measured by Immunoadsorption Scintillation Proximity Assay (ISPA). Soc Neurosci Abstr 25(Part 1): 1199

Corrigan MH (2000): Denahan AQ, Wright CE, Ragual RJ, Evans DL (2000) Comparison of pramipexole, fluoxetine, and placebo in patients with major depression. Depress Anxiety 11:58-65

Cusack B, Nelson A, Richelson E (1994): Binding of antidepressants to human brain receptors: focus on newer generation compounds. Psychopharmacology 114:559-565

Czachura JF, Rasmussen K (2000): Effects of acute and chronic administration of fluoxetine on the activity of serotonergic neurons in the dorsal raphe nucleus of the rats. Naunyn-Schmiedeberg's Arch Pharmacol 362:266-275

DasGupta K (1998): Treatment of depression in elderly patients: recent advances. Arch Fam Med 7:274-280

DeLapp NW, McKinzie JH, Sawyer BD, Vandergriff A, Falcone JF, McClure D, Felder CC (1999): Determination of ${ }^{35}$ S] guanosine-5'-O-(3-thio)triphosphate binding mediated by cholinergic muscarinic receptors in membranes from Chinese hamster ovary cells and rat striatum using an anti-G protein scintillation proximity assay. J Pharmacol Exp Ther 289:946-955

Di Matteo V, Di Mascio M, Di Giovanni G, Eposito E (2000): Acute administration of amitryptyline and mianserin increases dopmaine release in the rat nucelus accumbens: possible involvement of serotonin2C receptors. Psychopharmacology 150:45-51

Di Matteo V, Di Giovanni G, Di Mascio M, Esposito E (1998): Selective blockade of serotonin $2 \mathrm{C} / 2 \mathrm{~B}$ receptors enhances dopamine release in the rat nucleus accumbens. Neuropharmacology 37:265-272

Di Matteo V, Di Giovanni G, Di Mascio M, Esposito E (1999): SB 242084, a selective serotonin2C receptor antagonist, increases dopaminergic transmission in the mesolimbic system. Neuropharmacology 38:1195-1205
Ebert D, Lammers CH (1997): Das zentrale dopaminerge System und die Depression. Nervenarzt 68:545-555

Fibiger HC (1995) Neurobiology of depression: Focus on dopamine. In Gessa G, Fratta W, Pani L, Serra G (eds), Depression and Mania: From Neurobiology to Treatment. New York, Raven Press, pp 1-17

Gartside SE, Umbers V, Hajos M, Sharp T (1995) Interaction between a selective 5-HT1A receptor antagonist and an SSRI in vivo: effects on 5-HT cell firing and extracellular 5-HT. Br J Pharmacol 115:1064-70

Gobert A, Millan MJ (1999): Serotonin (5-HT)2A receptor activation enhances dialysate levels of dopamine and noradrenaline, but not 5-HT, in the frontal cortex of freely-moving rats. Neuropharmacology 38:315-317

Heinz A (1999): Anhedonia-a general nosology surmounting correlate of a dysfunctional dopaminergic reward system? Nervenarzt 70:391-398

Invernizzi R, Belli S, Saminan R (1992): Citalopram's ability to increase the extracellular concentrations of serotonin in the dorsal raphe prevents the drug's effect in the frontal cortex. Brain Res 584:322-324

Jenck F, Moreau J-L, Mutel V, Martin JR, Haefely WE (1993): Evidence for a role of 5-HT1C receptors in the antiserotonergic properties of some antidepressant drugs. Eur J Pharmacol 231:223-229

Jordan S, Kramer GL, Zukas PK, Moeller M, Petty F (1994): In vivo biogenic amine efflux in medial prefrontal cortex with imipramine, fluoxetine and fluvoxamine. Synapse 18:294-297

Kent JM (2000): SnaRIs, NaSSAs, and NaRIs: new agents for the treatment of depression. Lancet 355:911-918

Li X-M, Perry KW, Wong DT, Bymaster FP (1998): Olanzapine increases in vivo dopamine and norepinephrine release in rat prefrontal cortex, nucleus accumbens and striatum. Psychopharmacology 136:153-161

Lindvall O, Bjorklund A (1983): Dopamine and norepinephrine-containing neuron systems: their anatomy in rat brain. In Emson PC (ed), Chemical Neuroanatomy. New York, Raven, pp 229-256

Lindvall O, Bjorklund A (1978): Organization of the catecholamines neurons projecting to the frontal cortex in the rat. Brain Res 142:1-24

Lodge D, Webb D (2000): Comparison of R- and R,S-Fluoxetine following acute and subchronic administration on rat dorsal raphe neuronal excitability. ACNP Abstract 39:281

Lucaites VL, Nelson DL, Wainscott DB, Baez M (1996): Receptor subtype and density determine the coupling repertoire of the $5-\mathrm{HT}_{2}$ receptor subfamily. Life Sci 59:1081-1095

Malagie I, Trillat AC, Jacquot C, Gardier AM (1995): Effects of acute fluoxetine on extracellular serotonin levels in the raphe: an in vivo microdialysis study. Eur J Pharmacol 286:213-217

Millan MJ, Dekeyne A, Gobert A (1998): Serotonin (5-HT)2C receptors tonically inhibit dopamine (DA) and noradrenaline (NA), but not 5-HT, release in the frontal cortex in vivo. Neuropharmacology 37:953-955

Miller HL, Delgado PL, Salomon RM, Heninger GR, Charney DS (1996a): Effects of alpha-methyl-para-tyrosine 
(AMPT) in drug-free depressed patients. Neuropsychopharmacology 14:151-157

Miller HL, Delgado PL, Salomon RM, Berman R, Krystal JH, Heninger GR, Charney DS (1996b): Clinical and biochemical effects of catecholamine depletion on antidepressant-induced remission of depression. Arch Gen Psychiatry 53:117-128

Owens MJ, Morgan WN, Plott SJ, Nemeroff CB (1997): Neurotransmitter receptor and transporter binding profile of antidepressants and their metabolites. J Pharmacol Exp Ther 283:1305-1322

Owens MJ, Knight DL, Nemeroff CB (2001): Second-generation SSRIs: Human monoamine transporter binding profile of Escitalopram and R-Fluoxetine. Biol Psychiatry 50:345-350

Pani L, Gessa GL (1997): Evolution of the dopaminergic system and its relationships with the psychopathology of pleasure. Int J Clin Pharmacol Res 17:55-58

Pälvimäki E-P, Kuoppamäki M, Syvälahti E, Hietala J (1999): Differential effects of fluoxetine and citalopram on serotonin $5-\mathrm{HT}_{2 \mathrm{C}}$ receptor occupancy in rat brain. Int J Neuropsychopharmacol 2:95-99

Pälvimäki E-P, Roth BL, Majasuo H, Laakso A, Kuoppamäki M, Syvälahti E, Hietala J (1996): Interactions of selective serotonin uptake inhibitors with the serotonin $5-\mathrm{HT}_{2 \mathrm{C}}$ receptor. Psychopharmacology 126:234-240

Patinos G, Watson C (1986): The rat brain in stereotaxic coordinates. Academic Press, New York.

Perry KW, Fuller RW (1997): Fluoxetine increases norepinephrine release in rat hypothalamus as measured by tissue levels of MHPG-SO ${ }_{4}$ and microdialysis in conscious rats. J Neural Transm 104:953-966

Pozzi L, Invernizzi R, Garavaglia C, Samanin R (1999): Fluoxetine increases extracellular dopamine in the prefrontal cortex by a mechanism not dependent on serotonin: a comparison with citalopram. J Neurochem 73:1051-1057

Pullar IA, Carney SL, Colvin EM, Lucaites VL, Nelson DL, Wedley S (2000): LY367265, an inhibitor of the 5-hydroxytryptamine transporter and 5-hydroxy-tryptamine(2A) receptor antagonist: a comparison with the antidepressant, nefazodone. Eur J Pharmacol 407:39-46

Rajkowska G, Miguel-Hildalgo JJ, Wei J, Dilley G, Pittman SD, Meltzer HY, Overholser JC, Roth BL, Stockmeier CA (1999): Morphometric evidence for neuronal and glial prefrontal cell pathology in major depression. Biol Psychiatry 45:1085-1098

Richelson E (1996): Synaptic effects of antidepressants. J Clin Psychopharmacol 16(Suppl 2):1s-9s

Rubin E, Sackeim HA, Prohovnik I, Moeller JR, Schnur DB, Mukherjee S (1995): Regional cerebral blood flow in mood disorders: IV. Comparison of mania and depression. Psychiatry Res 61:1-10

Seth R, Jennings AL, Bindmann J, Phillips J, Bergmann K (1992): Combination treatment with noradrenalin and serotonin reuptake inhibitors in resistant depression. $\mathrm{Br}$ J Psychiatry 161:562-565

Stahl SM (1998): Mechanism of action of serotonin selective reuptake inhibitors. Serotonin receptors and pathways mediate therapeutic effects and side effects. J Affect Disord 51:215-235
Stein DJ, Hollander E (1994): Sexual dysfunction associated with the drug treatmant of psychiatric disorders. CNS Drugs 2:78-86

Stefanski R, Goldberg SR (1997): Serotonin 5-HT2 receptor antagonists postential in the treatment of psychiatric disorders. CNS Drugs 7:388-409

Strober M, Rao U, DeAntonio M, Liston E, State M, AmayaJackson L, Latz S (1998): Effects of electroconvulsive therapy in adolescents with severe endogenous depression resistant to pharmacotherapy. Biol Psychiatry 43:335-338

Van Bockstaele EJ, Biswas A, Pickel VM (1993): Topography of serotonin neurons in the dorsal raphe nucleus that send axon collaterals to the rat prefrontal cortex and nucleus accumbens. Brain Res 624:188-198

Van Praag HM, Korf J (1970): L-tryptophan in depression. Lancet 19:612

Wainscott DB, Lucaites VL, Kursar JD, Baez M, Nelson DL (1996): Pharmacologic characterization of the human 5hydroxytryptamine2B receptor: evidence for species differences. J Pharmacol Exp Ther 276:720-727

Weinshank RL, Zgombick JM, Macchi MJ, Branchek TA, Hartig PR (1992): Human serotonin 1D receptor is encoded by a subfamily of two distinct genes: 5-HT1D alpha and 5-HT1D beta. Proc Natl Acad Sci USA 89:3630-3634

Westenberg HG (1999): Pharmacology of antidepressants: selectivity or multiplicity? J Clin Psychiatry 60:4-8

Wong DT, Threlkeld PG, Best KL, Bymaster FP (1982): A new inhibitor of norepinephrine uptake devoid of affinity for receptors in rat brain. J Pharmacol Exp Ther 222:61-65

Wong DT, Bymaster FP, Reid LR, Mayle DA, Krushinski JH, Robertson DW (1993): Norfluoxetine enantiomers as inhibitors of serotonin uptake in brain. Neuropsychopharmacology 8:337-344

Wong DT, Bymaster FP, Engleman EE (1995): Prozac (fluoxetine, Lilly 110140), the first selective uptake inhibitor and an antidepressant drug: twenty years since its first publication. Life Sci 57:411-441

Wong EHF, Sonders MF, Amara SG, Tinholt PM, Piercey MF, Hoffmann WP, Hyslop DK, Franklin S, Porsolt DE, Bonsignori A, Carfagna N, McArthur RA (2000): Reboxetine: A pharmacologically potent, selective, and specific norepinephrine reuptake inhibitor. Biol Psychiatry $47: 818-829$

Yoshida K, Higuchi H, Kamata M, Yoshimoto M, Shimizu T, Hishikawa Y (1997): Dopamine releasing response in rat striatum to single and repeated electroconvulsive shock treatment. Prog Neuropsychopharmacol Biol Psychiatry 21:707-715

Yoshida K, Higuchi H, Kamata M, Yoshimoto M, Shimizu T, Hishikawa Y (1998): Single and repeated electroconvulsive shocks activate dopaminergic and 5-hydroxytryptaminergic neurotransmission in the frontal cortex of rats. Prog Neuropsychopharmacol Biol Psychiatry 22:435-444

Zgombick JM, Weinshank RL, Macchi M, Schechter LE, Branchek TA, Hartig PR (1991): Expression and pharmacological characterization of a canine 5- hydroxytryptamine1D receptor subtype. Mol Pharmacol 40:1036-1042

Zis AP, Nomikos GG, Damsma G, Fibiger HC (1991): In vivo neurochemical effects of electroconvulsive shock studied by microdialysis in the rat striatum. Psychopharmacology 103:343-350 